\title{
The devil in the number: Rethinking Garrett Hardin's The tragedy of the commons and global overpopulation crisis
}

\author{
Taiwo A. Olaiya \\ Department of Public Administration, Obafemi Awolowo University, Ile-Ife, Nigeria \\ "Go, go, go, said the bird: human kind \\ Cannot bear very much reality". \\ T. E. Eliot, Burnt Norton (1941)
}

\begin{abstract}
Critiques of the misconstrued thesis of Garrett Hardin's (1968) classic essay entitled The Tragedy of the Commons from the futility of technical solution for overpopulation crisis to concern of managing the commons are well documented. However, little is known of the remote and proximate causes of the pejorative confusion about the important essay. This article engages the discursive reconstruction of Hardin's thesis focussing on the original intent, which is the unscrupulousness of unchecked human breeding as the critical factor in the tragedy of the earth's commons. Deployed is an eloquent metaphor, the devil in the number, and thematic analysis of the (Hardin's) essay and systematic review of relevant and related literature before and after the essay was published in 1968. The texts reinvent and reinforce the illogic of overpopulating the world while simultaneously pursuing the technocratic solutions to nature's burden. The article reports four marked factors that swayed the perception of Hardin's thesis. In effect, the attempt stimulates a discourse showcasing the significance of Hardin's essay, particularly the global lackadaisical attitude towards overpopulation as a strategic, if not the single most important, factor in the overburdened ecosystem and, by extension, as the harbinger for the socioeconomic and governance crisis across the global divides.
\end{abstract}

Keywords: The tragedy of the commons, Ecological crisis, Human fecundity, Overpopulation crisis, Garrett Hardin

\section{INTRODUCTION}

$\mathrm{I}$ n environmental studies, controlled population as opposed to technological solution for environmental crisis remains essentially neglected. Notwithstanding, few scholars have attempted to mobilise the discourse on environmental challenges beyond the technology of ecological restoration, renaturalisation, reforestation and re-wilding. Unfortunately, studies on non-technical solutions to environmental problems have either been abandoned or reworked from its original thesis (Feeny, Berkes, McKay and Acheson, 1990; Gehrt, 1996). In 1968, a renowned ecologist, Garrett Hardin, published a thoughtful essay entitled The Tragedy of the Commons, which took the world by storm. In that excellent, well-quoted and well-critiqued epoch-making scholarship, Hardin queried the rationality in pursuing the technology of environmental restoration under the heavy yoke of an astounding 3.7 billion human number, as it were, and still rapidly counting. Arguably, the author transformed the narrative about overpopulation from the conventional, liberal and solution-driven tune to hard-line sustainable population strategies than never before. Hardin engaged global attention into a new normal in the seemingly futile scrambling against anthropogenic degradations much like William Shakespeare's admonition in Sonnet 3,

\section{Look in thy glass, and tell the face thou viewest}

Now is the time that face should form another;

Whose fresh repair if now thou not renewest,

Thou dost beguile the world...to stop posterity?

That is precisely where the anxiety of Shakespeare as a sonneteer connects with Hardin's ecologist's sobriety about human's freedom to breed. For both, humans pose a tragedy on the commons that is capable of beguiling the world and terminate posterity. Hardin was not alone in the terrifying human fecundity that causes the anxiety of all time. Crowe (1969: 1103) discussed about the "population atomic war" that could "threaten the very existence of the contemporary man". Gehrt (1996) about the damaging "inability of most people to comprehend large [human] number" and the minimisation of "the extent of population growth" on the environment. Sandvik (1999) considered the inevitable critical stage that population number poses on the existing global resources. The writer argued the number may not of its own pose any challenge; a certain comprehensible end is that the reduction in per-capita share will keep diminishing. As Jermain (1975, p. 14) argued, concern about overpopulation arose "from the earliest cultures of man". Jermain says further of overpopulation,

"The earliest religious teaching, Zoroastrianism, Hebrew teachings, and early Greek mythologies include concerns for population... Plato and Aristotle struggled with the idea of optimum population... Both city-states and Plato and Aristotle recognized the possibility of overpopulation" (pp. 14-15). 
The anxiety of overpopulation has, therefore, run through historical epochs of the ancient, medieval, Malthusian, Marxist, and to the modern age of sustainable development. In the same year of Hardin's publication, Paul Ehrlich published a book titled The Population Bomb, where he detailed the 'new brutality' of 'terrifying' overpopulation and its attendant effects on the environment (Ehrlich, 1968:xiii). As Sheperd (1988, p. 1) pointed out, "the seeming mad irrationality" of man to procreate with unbridled abandon might have "prompted Hardin to write with such passion and despair of the commons".

Curiously, references to the article have, most often than not, centered on the calamity inherent in uncooperative management of the commons. Whereas, Hardin's (1968) essay aimed at proffering non-technical solutions to ecological crisis by reducing the prevailing excessive fecundity, which has been largely taken asunder. Twenty-two years after the publication, Feeny et al (1990:1) argued that the enduring legacy of Garret Hardin's paper is "its metaphor of commonproperty resource management" despite the clear focus "on overpopulation". Without doubt, Garrett Hardin shares part of confusion through certain effusive over-calibrations in the article and rejoinders published by the author presumably from the overwhelming references attracted by the article.

In the introduction to the essay, Hardin denounced the seemingly persuasive promotion of 'technical solution' for tackling the accelerating population crisis and pointed global attention instead to the idea of coercive suasion against unbridled fecundity and global political will that seek to lay little or no emphasis on 'a change only in the techniques of the natural sciences'. Stating bluntly that solution lies neither in intensified aquatic products farming nor in "developing new strains of wheat" to feed the burgeoning population but in dramatic "change in human values or ideas of morality" to reducing the prevailing excessive fecundity. Identified, and defied, by Hardin was the reigning and seemingly insurmountable assumption that was hitherto universal and, perhaps till date, about finding technical solutions to environmental crisis. Hardin cited two preliminary examples. One, a dauntless article by Wiesner and York (1964) that reprobated continued nuclear arm sciences and technology in the heat of cold war between the West and the East, and second an analogical "game of tick-tack-toe" that "cannot" ensure real-time victory should a player keeps up "with the conventions of game theory". Both circumstances, as Hardin pointed out, require thinking outside the box from the fixated science and technology ideals to environmental rationality for population control. Hardin took to the bleachers (i) the laissez-fair values of Adam Smith's "invisible hand"; (ii) Jeremy Bentham's simplistic goal of "the greatest good for the greatest number"; (iii) the United Nation's 1967 Universal Declaration of Human Rights; and (iv) the Margaret Sanger's 1911 Planned Parenthood reproductive technology. For him, they all lack the "susceptible consciences" that prioritises the necessity of the moment to slow down procreation. They are, as Harding pointed out, the harbingers and embracers of, if not succumbing to, the 'liberal... [but] tragic ideal' of the fecundity that precipitated the population growth across the ages.

To explore this, Hardin deplored a well-expressed allegory of two herdsmen who, faced with an unrestricted pastureland for grazing their cattles, coveted and overburdened the gracingland to a guaranteed extinct. The idea of the commons, as Hardin posited, refers to a valuable natural resource accessible to all users and every use subtracts from the main. Each being a rational human being would ordinarily plot to maximise and personalise gains from the system while simultaneously minimise losses that inevitably accentuate from every single addition of cattle by all users. No doubt, the herdsmen allegory was indeed rendered with graphical creativity and literal finesse. But then, it is just one of the illustrative mains that Hardin utilised to drive home his focal point-moral, rather than technocratic, sentiment to solving the hiked and hiking overpopulation crisis. There are other illustrations bordering on economics, demography, psychology and resource administration in the epic essay.

Yet, Hardin's The Tragedy of the Commons has been more intensely interrogated, and in fact made popular, by its incessant references for resolving the misfortune attributable to management of the commons and the enthusiasm embedded in rational consummation of earth resources. Such fixation apparently stymied the very thesis of the epic work. How did the scholarly and opinion world get consumed in an illustrative allegory and, not in the least, to the detriments of the overarching thesis? What factors account for making other nuances in the essay so diminutive and inconsequential? In this article, we engage a discursive reconstruction of the highly patronised notion of the calamity inherent in uncooperative management of goods held in commons as revealed in the general allusions to Garrett Hardin's (1968) essay. In specifics, we examine the nature of the title in the literary sense to interrogate why references to the work oftentimes relate to more to over-exploitation of earth's finite resources as against the environmental crisis inherent in overpopulation of Homo sapiens. Given the express proclamation by Hardin in the background statement of the essay, we examine how much the declared thesis of the essay deviated from the 'perceived' thesis.

\section{Problem Statement}

The article critically examines the thesis in Hardin's essay in its novel intent about the amorality of the current and festering fecundity as a fundamental factor that remains critical to the looming collapse of the earth. Using an eloquent metaphor coined the devil in the number, this article attempts to reinvent the illogic of overpopulating the world while simultaneously pursuing the technocratic solutions to nature's burden. The method is neither abstract nor philosophical. The article utilised basic analytical logic for reasoning out answers to the research questions. Materials and methods from sociological, 
economic and political perspectives are combined to make a case with the continued global tension about salvaging an already burdened and polluted ecosystem through sustainable production, consumption and mercantile plans. Hardin's penetrating article needs critical revalidation in its original thesis for the urgency of population control rather than the pervasive fixation towards the technologies of managing the overburdened commons and creating an earth-friendly ecology.

The ultimate, here, is to put to literal, literary and scientific test to the actual thesis of the Hardin's thesis. According to Hardin (1968, p. 1244), "man is locked into a system that compels him to increase his herd without limit — in a world that is limited". What locked man? What system? To Hardin, the entire global thinking has been utterly derailed from the realities of the human number. All attempts to tackle to task of overbreeding is met with high-sounding condemnations such as elitism, big-brotherism, despotism, and fascism As Hardin would later argue in 1993, "We are slow to mend our ways because ethicists and philosophers of the past generally did not see that numbers matter. In the language of 20th-century commentators, traditional thinking was magnificently verbal and deplorably non-numerate" (Hardin, 1993). For him, the existential 'devil' in nature's burden is human's freedom to breed. Yet, the view that Hardin's work is about managing the commons prevails in the literature. What factors accounted for the seeming rededication? Hardin's essay's advocacy for nontechnical solution to environmental crisis appears to have been equally side-lined. How much of sustainable production, consumption and mercantile plans could salvage the ecosystem from man-made hazards? The accompanying anthropogenic factor inevitably emanating from the stunning human number appears to escape researcher's attention. To what extent does technology offer exclusive solution? Megacities are getting swollen and new ones are sprouting by the day. With percentage urban to total population rising steeply by the years and about two-third of the global population residing in the cities as of 2019 (The World Bank, 2021), what technology can sustainably assuage the burgeoning needs of the escalating urban population? Humans have taken up a great percentage of earth's resources, leading to accelerating loss of biodiversity and environmental despoliation.

In a world of about 7.7 billion people and about 83 million annual increase, what level of nature's rewilding, reforestation and conservation projects could curb the existing (ensuing) ecological crises? What 'mutual coercion', using Hardin's words, could be 'mutually agreed upon' to practically halt the skyrocketing human population and to avert the looming 'tragedy of the commons'? How may human's thoughtprocess be reimagined, as Harding long suggested, to recognise that "freedom to breed is intolerable" in our present ecosystem? As Hardin contemplated, what "recognition of necessity" and futility of technical solution can humans proclaim 'without apology and embarrassment'? These are the questions raised in this article. Using trans-disciplinary narrative grounded in economics, politics, history and social anthropology, as well as pedagogical narrative method, this article will critically examine the gamut of literature on Hardin's Tragedy of the Commons. Among others, the focus will principally examine human factors, market tensions, and liberty that arguably motivated the thesis in Hardin's essay. My intention is not to re-propound Hardin's hard-line thesis to human fecundity but to stimulate its fascinating and highly suggestive submissions in the discourse of today's environmental studies for sustainable population strategies. I argue that the contemporary global best practices for environmental issues, such as sustainable development strategies, buen vivir (good life) principles in the Andean countries of Bolivia and Ecuador, and the Nyerere's commensalism in Africa are, in Hardin's words, technocratic 'pathogens' and 'self-eliminating' appeals to the unstable prejudice and fluid conscience of man. Whereas the sheer number of human beings, his freedom to breed and the romanticism of liberal principles of 'human right' would always tip the mother earth towards overpopulation and environmental crisis. Using the eloquent metaphor coined the devil in the number, we argue for the illogic of pursuing the technical solutions to nature's burden while simultaneously overpopulating the world and ignoring the accompanying Anthropocene.

\section{METHOD AND MATERIALS}

This research is a qualitative analysis of the texts and contexts of Garrett Hardin's 1968 epic essay titled The tragedy of the commons and related materials, as well as other tangential classic works on population and the environment undertaken by authors across the time. As an essay whose main object addressed overpopulation, issues bearing on population are also reviewed through the lenses of various writers. Specifically adopted for the research is a combination of thematic analysis and systematic literature review in which the set objectives are transliterated into research questions within the bounds of the scope and justifications. Thematic analysis refers to a qualitative research method, which could be deployed for a broad-spectrum epistemological analysis and research questions. As Braun and Clarke (2006) argued, thematic analysis allows a researcher to identify, analyse, organise, describe, and report themes existing in a data set. The questions are critically addressed ad seriatum in line with the original thesis of Hardin's essay as unequivocally stated in the abstract and objectives, as well as elucidated in the body of the author's essay. The major themes for this research are overpopulation, fecundity, population growth, management of the commons, ecological crisis, among others. Since thematic analysis hardly requires that a researcher possess an adequate understanding of the theories and technologies utilised for other qualitative approaches (Nowell, Norris, White \& Moules, 2017), it offered a suitable access to qualitative analysis of the themes. Similarly, a systematic review allows the collection of possible studies that are relevant to a 
particular subject matter and prosaically reviews and analyses the findings (Ahn \& Kang, 2018).

\section{Research objectives and questions}

The broad objectives of this unique research endeavour is to elicit the original intent of Garret Hardin's essay titled The tragedy of the commons, which is overpopulation crisis. The specific objectives are to

i. Identify the contending issues that stymied the conception of Hardin' reputable essay from its original focus on overpopulation to management of the commons;

ii. Evaluate the textual contents the essay in the aftermath of its references as a strategic concern for managing the commons;

iii. Analyse the lateral and collateral consequences of misconceiving the essay on the lingering overpopulation debate since 1968; and

iv. Discuss the ontological significance of the essay for the socio-economic and governance crisis across the global divides.

Flowing from these, the research engaged the following questions:

i. What contending issues stymied the conception of Hardin's thesis from its original intent about overpopulation to management of the commons?

ii. How did (does) the textual content of the essay contribute to the aftermath of its references as a strategic concern for managing the commons?

iii. To what extent could Hardin's essay have engaged the seemingly unending conversation on overpopulation since its publication in 1968 ?

iv. What relationship could have emerged from overpopulation focus, which Hardin focused, and the existence, being, becoming and reality of the contemporary governance crisis in all parts of the world?

\section{REVIEW OF EXTANT LITERATURE}

Establishing Garrett Hardin's thesis: The gun versus the bullet

The pivotal thesis of the Hardin's essay, which explores nontechnical solution to crisis of overpopulation, is metaphorically described here as the gun, while the illustrative agents like the commons and pastureland users are collectively referred to, in the same manner, as the bullet. The gist here is not to weigh the essentialities in the two, for each literally complements the other in concrete terms. Instead, the idea is to declare that one cannot replace the other in status and functions. Nothing else fires the bullet to the required velocity than the gun. Perhaps, a gun is no more than a club if emptied of its bullet(s). In other words, how lethal a weapon is a gun if the chambers are emptied of bullets? As persuasive as the complementarity notion of 'bullets as the whole essence of a gun' may appear, the unique position of the gun, as the overall concern of firearm subscribers, is arguably inimitable. A fair answer might be that each is insufficient by itself. The gun fires the bullet in the direction of the 'target'. To the extent of the range and lethal composition of the gun, the bullet moves to devastate. As Garrett Hardin indicated in the work, the overarching thesis of his work concerns overpopulation. His metaphoric illustration of the herdsmen and the commons (grazing grounds) that gets rapidly depleted appears to have gained more attraction than the original focus of the essay. In this section, the original thesis is taken as the gun, while the illustrative analytics is the bullet.

The thesis of a study is the gun that should, by the same token, gain more notoriety than any illustration, notwithstanding the latter's appeal. Going by the preponderance of references to Hardin's The Tragedy of the Commons, that illustrative part about the allegory of the herdsmen gained more prominence than the thesis of the article itself. To establish the thesis of the essay, we embarked on a dispassionate dissection of its components. A section-by-section analysis of Hardin's essay would reveal the consistency of its thesis - exploring a nontechnical moralistic value changes to the hazard that overpopulation exerts on the world's finite resources. Reading through Hardin's work, the element of morality towards attitudinal change to global population control is key. In the background statement, Hardin declared unequivocally thus:

"My thesis is that the "population problem," as conventionally conceived, is a member of this class. How it is conventionally conceived needs some comment. It is fair to say that most people who anguish over the population problem are trying to find a way to avoid the evils of over-population without relinquishing any of the privileges they now enjoy. They think that farming the seas or developing new strains of wheat will solve the problem - technologically. I try to show here that the solution they seek cannot be found. The population problem cannot be solved in a technical way" (Emphasis supplied)

Concluding, Hardin stated that

"The most important aspect of necessity that we must now recognize, is the necessity of abandoning the commons in breeding. No technical solution can rescue us from the misery of overpopulation. Only so, can we put an end to this aspect of the tragedy of the commons". (Emphasis supplied)

The tenacity of the thesis around the subject matter of unchecked population growth is arguably indubitable. Hardin commenced with unsettling the simplicity in Thomas Malthus's positive and preventive checks to population growth. In his epic book, An Essay on the Principle of Population, published in 1798 Thomas Malthus raised two 'postulata': that unconstrained population is bound to increase at geometric ratio while man's subsistence tends only to improve at arithmetic ratio. To "prevent an increase of [human] numbers beyond the ability of the country to 
support" Malthus suggested both preventive checks through late marriages and unmarried lives and positive checks through famine and ecological crisis (Malthus, 1798:18-31).

Hardin however posited that the idea of checks from natural disasters and planned fecundity could hardly stem the tide of the current population growth, let alone tame it. As Hardin argued, the arrangements discernible in Malthus's essay embed the rationality of human in taking rational decisions about his immediate environment. The idea would seem to be adequate at the time due to 'centuries' of 'tribal wars, poaching, disease' that kept the populations of human being and animals in constant check (Hardin, 1968: 1245). However, the workability of such would appear inadequate to produce the checks to the geometrical (now exponential) population growth. The emergence of 'social stability' of human race in which industrial revolution, improved control on epidemics and global mechanisms for conflict prevention and management, as well as interconnectedness of global actors for aids and assistances have all combined to pale the checks proposed by Malthus. As Olaiya (2016) opined, Malthus arguably did not foresee the effective hybridization of the current food production, preservation and supply chain system and the highly advanced development in the area of medicine that have combined to keep a large volume of humans on earth surface. The global diplomatic and cooperative technology that led to the formation of the League of Nations and later United Nations and all the appendages for the maintenance of global peace rapid response system for preventing and managing conflicts, pandemics, and mishaps is arguably not foreseen by Malthus. Since it's now feasible to produce human subsistence as geometrically as population growth; and minimise human mortality from wars and natural disasters, the question of Malthusian checks would not suffice. Hardin's essay thus argues that the important step to taming the size of human needs that necessitate overexploitation, pollution and environmental despoliation is, above all else, to reduce human numbers by mutually and coercively curtailing human's freedom to breed.

\section{Overpopulation crisis: The devil in the number}

The central submission of Hardin's essay is that, logically, every increase in human population in a finite world such as ours "must steadily decrease...the per capita share of the world's goods" (p. 1243). Hardin posited that zero population growth, as it were, will not guarantee Jeremy Bentham's "greatest good for the greatest number" not to mention the current exponential increase inevitable in the contemporary value system. As Hardin deduced, an improvement in mode and energy supply should be capable of bridging the wide gaps in Malthus's postulate of the geometrically growing population growth and food security growing at arithmetic rate. In addition, Malthus's propositions did not factor the human inducement of natural disasters through excessive production of food into his ration analysis. The totality of the effects the current mammoth population, which in all logical sense appears to be incipient to the looming population bomb, is only imaginable.

Between the advent of agrarian economy and 1 A.D. (spanning approximately 8000 B.C.), world's population increased from about 5 million to somewhat 200 million. Between 1 A.D. to the dawn of industrial revolution (in approximately 1500 years), human number had increased from 200 million to about 500 million. At the dawn of agriculture, about 8000 B.C., the population of the world was approximately 5 million. Over the 8,000-year period up to 1 A.D. it grew to 200 million (some estimate 300 million or even 600, suggesting how imprecise population estimates of early historical periods can be), with a growth rate of under $0.05 \%$ per year.

A tremendous change occurred with the industrial revolution: whereas it had taken all of human history until around 1800 for world population to reach one billion, the second billion was achieved in only 130 years (1930), the third billion in less than 30 years (1959), the fourth billion in 15 years (1974), and the fifth billion in only 13 years (1987). At the time Thomas Malthus was writing his epic book in 1798 the world population was approaching 1 billion people (Anson, Bartl \& Kulczycki, 2019). A fabulous transformation took place after the industrial revolution when the world recorded 1 billion human beings around 1800 A.D. The sequence that followed has been alarming. Even though the world had to exist till around 1804 A.D. to net the first 1 billion, the next billions were attained successively in 1927, 1960, 1975, 1988, 1999 and 2011 at approximately 125 years, 33 years, 15 years, 13 years, 11 years, 12 years respectively. The world population currently stands at about 7.4 billion and is projected to attain 8 billion, 9 billion and 10 billion in 2025, 2043, and 2083 respectively. Right from around 1750 to the present time, global population stood above moving averages (Figure 1).

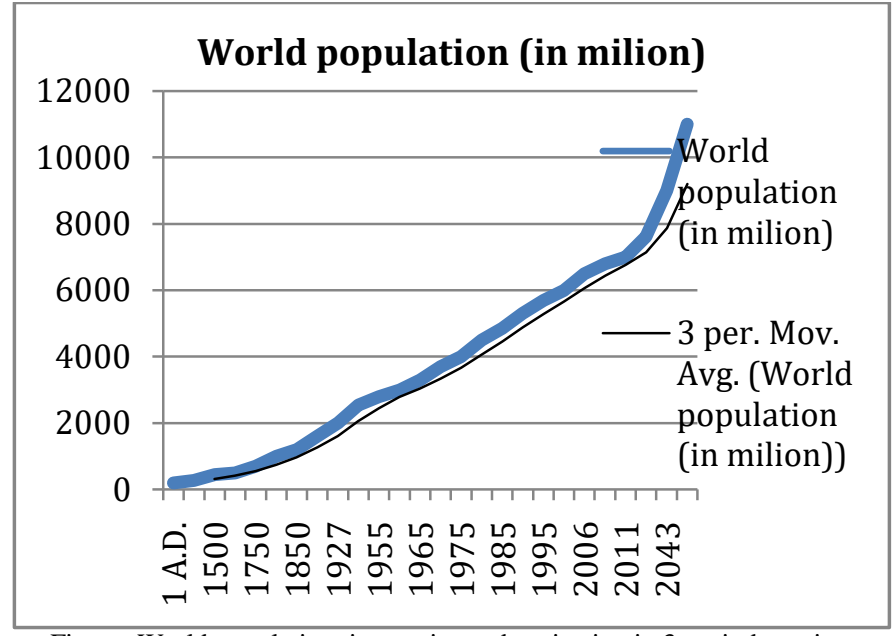

Figure: World population time series and projection in 3-period moving average.

Source: Rosemberg, M. (2017); Anson, Bartl \& Kulczycki (2019); Current world population: world population growth from the year 1 A. D. Accessed 23/08/17 from https://www.thoughtco.com/current-world-population$\underline{1435270}$ 
The devil in the number, the manifestations of tragic socioeconomic events such as ecological disaster, epidemics and pandemics, nuclear plant explosions, loss of biodiversity, ocean acidification, eutrophication, air pollution events unbridled human fecundity leading to galloping population growth, cannot be overemphasised. With the world population at over 7.5 billion in 2019 and projected to exceed 11 billion by 2099 , it stands to reason that human needs have greatly increased beyond the finite supply of earth's resources. The condition may neither be attributable to social conditions and responses from capitalism, as Marx opined around the midnineteenth century, nor to means of subsistence as Adam Smith argued in 1776 and later Thomas Malthus in 1798, nor to sustainable development plans propositioned by Jeffrey Sachs in 2015. The composite necessity to cater for the personal, household, and social living conditions of about 8 billion human beings is already weighing down on the planet and socio-political and economic systems. There is no gainsaying that biodiversity is thinning out fast because human number is clouding out other plant, animal and inanimate species. The outbreak of COVID-19 revealed how a pandemic could, in no time, afflict in great number and easily overwhelm the (supposedly) organised system of an advanced healthcare system. Within five months of its outbreak, the World Health Organisation (WHO) reported over 170 million confirmed infections of COVID-19 in all the world regions, including 3.5 million deaths (WHO, 2021). The outbreak of COVID-19 has been linked to overpopulation (Starkey, 2020; Islam, Ira, Kabir \& Kamrujjaman, 2020).

The decided misanthropy about overpopulation expressed in 1971 by Thomas Jukes in his essay entitled Overpopulation is beginning to crystallise into reality in the light of the rapidity of COVID-19 spread. In the author's words, "any death from a communicable disease must be attributed to overpopulation" because the latter compounds the system that mars real-time manageability (Jukes, 1971, p. 475). Overpopulation, as Jukes (1971) argues, is "the primary cause of death" in today's overcrowded world, which "must logically include all manmade fatalities, including wars, automobile accidents and, most of all, procreation" (p. 475). The paradox expressed by Hardin (1971, p. 486) that "Nobody ever dies of overpopulation" yet, in all parts of the world, "people are dying now of respiratory diseases...because of the "need" for more industry" is instructive.

In all, the tragedy, as ecological facts currently speaks, is an end unto itself and that portends the idea of the devil in the number. Hardin (1971) vivid captured the devil with a scathing irony,

The 'need' for more food justifies overfertilisation of the land, leading to eutrophication of the waters, and lessened fish production-which leads to more "need" for food (p. 486).

The situation remains as inconceivable as Paul Ehrlich warned in 1968 if the current trend in population growth is allowed to persist for 900 years. At that time, the population will be sixty million billion with 100 persons occupying a square yard of the combined land and sea surfaces, housed 2000 storey buildings. At some point, Ehrlich (1968) wrote about 'heat limit' in what Hardin (1971) called 'heat prostate'.

\section{RESULTS AND DISCUSSIONS}

\section{Hardin's misconstrued thesis: Justified or not?}

The abstract to Hardin's essay appears to speak for itself. It reads: "The population problem has no technical solution; it requires a fundamental extension in morality" (Hardin, 1968: 1243). Given the abstract, the declared thesis (already quoted) and a whole gamut of excerpts from the essay that speaks more to the lingering population crisis than anything else, the existing and continued allusion to the essay as a management kit remains a mirage. Perhaps, however, there are grounds for Hardin's thesis to be misunderstood; the imbalance set by over-emphasising the idea of the commons and the dearth of steadfastness in his consistency of the thesis's advocacy only set the ball rolling. Thus, why the much-quoted essay became an object of subverted focus is hardly a mirage: partly attributable to the essay itself and partly to the authors that critiqued or referenced the work. Fundamentally, most references took the article headlong from the title, The tragedy of the commons. By that very reasoning, decades of references oftentimes associated the article to sustainable resource exploitation. Nonetheless, the view about the 'tragedy' and the 'commons' diverted crucial attentions away from Hardin's thesis, which is the backlash inherent in overpopulation as the tangible factor precipitating nature's collapse, and collapsing response capabilities. Thoughtfully, Hardin was apprehensive about sheer size of human number, most notably the growth rate, as the tragedy reflecting in the complexities for managing the commons' adverse manifestations such as ocean acidification, ozone depletion, melting of the polar glaziers, among other convoluted manifestations of overpopulation.

From available literature analysed for the work, most critiques, appreciations and anthologies on the essay have centered on shared resources (commons) and the inevitable calamity on the commons that awaits its overuse. Elinor Ostrom's book published in 1990 Governing the Commons: The Evolution of Institutions for Collective Action arguably occupy a central position in what Maclellan (2015) called a, "entirely superficial reading of Hardin's argument" and "one that fundamentally" derailed the "object of [Hardin's] critique" (Parenthesis supplied). Elinor Ostrom's (1990) book, like others before an after it, misread the thesis of Hardin's essay for an important reason-not in the least that the book centered on disproving Hardin's (1968) postulations about the commons and thereafter earned Elinor Ostrom the prestigious Nobel Laureate in Economic Sciences in 2009. Despite admitting that "Hardin himself used the grazing commons as a [mere] metaphor for the general problem of overpopulation", Elinor Ostrom (1990) treated the scenario as though managing "resources that are subjected to the possibility of a tragedy of the commons" were the thesis of Hardin's The Tragedy of the 
Commons. In that book, Elinor Ostrom (1990) wrongly assumed that Hardin (1968) envisioned the 'degradation of the environment by using the tragedy formula to 'illustrate the logical structure of his model'. Arguing that Hardin (1968) has powerful voice as forbearers in the tragedy of the common thesis, she conflated the essay with the erudition of various scholars in political-economy, notably Aristotle whom she quoted as stating that "what is common to the greatest number has the least care bestowed upon it. Everyone thinks chiefly of his own, hardly at all of the common interest". Similarly, Elinor Ostrom (1990:2-3) also argued, coherently but wrongly, that Hobbes's "parable of man in the state of nature" (Quoted by Ostrom, 1990, p 2); William Forster Lloyd's (1833) theory that postulated an "improvident use for property owned in common" (Quoted by Ostrom, 1990, p 2); H Scott Gordon's (1954) theory of foolish fisherman in a common property (Quoted by Ostrom, 1990, p 2); among others, are a "prototype of the tragedy of the commons: Men seek their own good and end up fighting one another".

Recently, Maclellan (2015) argued that the critical mass of works carried out to critique or subscribe to Hardin's work missed the thesis. The author argued that the thesis of The Tragedy of the Commons "is not the commons or shared property at all" as most works referencing it appear to have queued "but is rather Adam Smith's theory of markets and its viability for protecting scarce resources". This position is equally wrong. As it can be deciphered from the entire text of Hardin's work, protecting our collective natural environment by enclosing the commons 'wherever they remained open and free' is not what requires a global and well-coordinated 'political priority' as it appears in Maclallan (2015), but making the "rapidly growing populations on earth" to be "eventually equal zero" by "abandoning the freedom to breed" (Harding, 1968). If anything, Maclellan's (2015) diagnose suffers the same fate as the almost 'universal' misconception it appears to redeem. Fecundity, not economic growth, is Hardin's grouse with Adam Smith's invisible hand theory. Hardin, in fact, argued that the audacious Adam Smith's analysis that individual pursuance of gains permeated by 'invisible hand' transposes into public gains portends a laissez-faire tendency and conceptual technical strains that is capable of constituting a major setback to calculated attempt for stemming down overpopulation.

If Hardin indicated to the market institutions at all, it is a tangential allusion to the peril on the environment for utilising the 'laissez-faire' theory in a world where a rational user is wont, by ambitiously increasing his stock, to meet the astronomical increase in the demand for his product as conditioned by the overpopulated public. Essentially, Hardin intended to, and did, rebut that since the so-called invisible hand determines equilibrium price, such technical mechanism may tend to flop in the face of high population. The question is what will farmers, fishers, and other commons users do knowing the demand conditions of the market is more expansive than he could supply? Beyond and with respect to
Hardin's postulations, the farmers will, most intelligibly, severally and jointly find means to till the soil more in meeting the upsurge in demand while increasing the volume of sale to increase profits. The need to "explicitly exorcise the spirit of Adam Smith in the field of practical demography" is, arguably, the crux of The Tragedy of the Commons (Hardin, 1968, p. 28). In sum, Adam Smith's highly influential "tendency of thought", in Hardin's words, is capable of adversely influencing

"positive action based on rational analysis,
namely, the tendency to assume that decisions
reached individually will, in fact, be the best
decisions for an entire society. If this assumption is
correct it justifies the continuance of our present
policy of laissez-faire in reproduction. If it is
correct we can assume that men will control their
individual fecundity so as to produce the optimum
population".

Similarly, Hardin asserted that Jeremy Bentham's goal of securing 'greatest good for the greatest number' is infeasible in a world where the best possible energy production and technique, including nuclear energy, cannot cope with the number of people.

Despite the seeming clarity in the thesis, the essay has been more inundated with subversion of its original idea, which are the hazards of overpopulation, than understood. If anything, the notion of commons as an economic decision by government, rather than as a modelling for procreation as commons that need political intervention, have pervaded the critiques of the work. Could part of the confusion be what Angus (2008a) pointed out that Hardin's essay is more often cited than read? Or are there other ontological reason(s) responsible for such wild goose chase? Did Hardin run foul of what Balch (2012) tag the crucial but oft-neglected task in technical writing? Hartley (2012) stated almost poetically that "[t]oday, too many titles lack crucial information and are thus misleading". Does Hardin essay lack essential information about the thesis? Bavdekar (2016) argued that "titles for research articles" should necessarily align with the "tenor of the paper". To what extent was the title of Hardin essay diverting and uproarious to becloud the thesis? Nevertheless, while the authors of the critique provide neither answers nor framework for these crucial questions, four factors that possibly triggered the monolithic misconception of Hardin's essay's thesis are lined up here:

\section{Misleading titling and modelling}

Since the first scholarly work was published around 1665 (Kumar, 2013), the need to appropriately structure articles from effective titling to conclusive remarks have increased and improved with tremendous rapidity. Scholars have found several use of a research title (1) Title triggers the first determinant for readability of articles (Rodrigues, 2013; Kulkarni, 2013, Kumar, 2013; Grant, 2013); (2) provides information about the content and detailing the study design 
(Bavdekar, 2016; Grant, 2013, Kulkarni, 2013; Hartley, 2012; Balch, 2012; Grant, 2013); (3) serves as the most available to readers through databases and tables of contents (Jaques \& Sebire, 2010; Fischer \& Zigmond, 2004; Vienna Scientific Sessions, 2016); and (4) attracts the attention of the right readers to the article (Mark, 2012), among others. Throughout scholarship history therefore, scientific researches have anchored on the appropriateness of titles for expedition and textualisation of the results. How much content(s) should be represented in the title of a research work? How much should a title connect to the modelling of a work and both to the thesis of the work? Scholars have argued that the essence of titles cannot be overemphasised as a principal factor determining the readership of a research work Kumar, 2013; Fischer and Zigmond, 2004). Whether nominal, compound or written as a full sentence, as Kumar (2013) typified, the important thing is that titles should effectively connect to the focus and context of the research. Balch (2012) submitted that titles are the often-neglected yet crucial step in writing. Editage (2013) investigated accessing title of a paper and subsequent readers' interest in the complete work. Results revealed that an average of only one out of every 500 who read the title of a paper would likely read the complete paper.

There are indications that this important step in a research appears to have been overlooked in Hardin's essay. In essence, the titling and modelling of the essay around the subject matter of 'the tragedy' and 'the commons' critically affected the path of its references. With such huge subversion from the reality of an important thesis as Hardin's, few would dispute that title goes beyond what Bavdekar (2016) described as "the gateway to the contents of a scientific article" or what Editage (2013) argued as enhancing "the impact or visibility of a work". Hardin's essay attracted the needed vicissitude in both scholarly and public opinion but with a subverted context. Titles are, therefore, the lifeblood of a research, determining the focus and content of an academic essay. Indeed, a title is the thesis of an essay put succinctly. Shepherd, 1988 argued

\begin{abstract}
"Nowadays, it is often forgotten that Hardin was prompted to write not by the misuse of common lands, but by population growth rates...the illustration he used of individual rationality leading to mass irrationality- that of the individual herder maximising his cattle on communally owned grazing at the expense of other herders".
\end{abstract}

There is therefore no doubt, from both references and critiques of Hardin's essay, that authors got stalked in the commons management and the irrationalities resulting from rational human choices. Angus (2008a) critiqued the work that 'the very fact that for centuries "rational herdsmen" did not overgraze the commons' belies Hardin's basic assumption, which makes it 'a circular argument that proves nothing'. Subsequently, Angus (2008b) queried why Hardin would assume that man's instinct opposes commons. Critiquing the essay, scholars have argued that Hardin's essay betrayed inexperienced understanding of social regeneration system of societies, the ignorance of private ownership of herds-field, absence of legal priviledges and rights. (Bromley \& Cernea, 1989; Appel, 1993).

That the title of Hardin's essay speaks to the modelling requires no further proof. The title The Tragedy of the Commons, read literally or cognitively, signalled an unintended calamities, which inevitably awaits open access resources users as a result of instinctive will of man, as a rational being, to oversubscribe the commons for parochial gain. Hardin's model follows coherently with the title as though managing the commons were his intentions.

The tragedy of the commons develops in this way. Picture a pasture open to all. It is to be expected that each herdsman will try to keep as many cattle as possible on the commons...As a rational being, each herdsman seeks to maximize his gain. Explicitly, or implicitly...the rational herdsman concludes that the only sensible course for him to pursue is to add another animal to his herd. And another, and another... Therein is the tragedy. Each man is locked into a system that compels him to increase his herd without limit - in a world that is limited. Ruin is the destination toward which all men rush, each pursuing his own best interest in a society that believes in the freedom of the commons. Freedom in a commons brings ruin to all.

Further analysis however revealed that, while modeling the essay, Hardin might have got lost in the amazement of the literal values of the title that he forgot the literary sense for which he meant the title. In a sense, the title appears designed to draw reader close than it aligns with the thesis. The author hinged too elaborately on the ruin that follows the rational choices of the herders in the commons and failed to immediately or focally connect the model to the gap he intended to fill. A closer look, however, would reveal that Hardin could not have meant that the metaphor casts in tragedy and commons would elicit such fixation in any historical or empirical sense, as most literature (mis)construed him. Again, this is presumptuous: only that the presentation of the core content of the work leaves little option as to such assumption. The mission that the devil to the world environmental crisis lies in the number of humans on earth surface featured prominently in the essay considering the opening part of the metaphoric model where Hardin stated that the 'rebuttal to the invisible hand in population control...may well' be called The Tragedy of the Commons. However, reading through the rest of the model, it appears difficult to blame authors for the fixation on the commons as both historical and empirical analysis of the essay. In sum, what appears missing is the crucial nexus between the title and modelling on the one hand and the thesis of the essays on the other hand. 


\section{Misleading textual contents}

A context in which a paper is crafted determines, not only the readership and impact on scholarship in the subject area, but also the framework for which readers perceive and utilise it for further research. As Kumar (2013) argued, writing 'a research paper... is not just to tell about your exciting research results to the world' but to convey the context of the thesis. Hardin was careful to state the overpopulation focus of his essay, albeit inconsistently, throughout the length of the essay. Yet, the tenor, in a good part, veered away from the thesis in not too familiar way of research in science. Angus (2008a, p. 1) agued that the 'texts' of The Tragedy of the Commons may have depicted authority and science, however, "it fell far short of science" in rigour and consistency. In a research on the Culture of Scientific Research in UK, the Nuffield Council on Bioethics (NCB, 2013) argued that rigour and accuracy were rated top two determinants of high quality research philosophy and practices in science. However, the essay is also, in some ways, not so attributable as humanities because, as Aikenhead (2007, pp. 1-2) argued, "humanistic perspectives in the science curriculum" included "the social aspects of science, and the human character of science revealed through its sociology, history, and philosophy", which is arguably lacking in the essay. Thus, if considered as a humanistic science essay, there are also basic historical inaccuracies in the metaphoric modeling. Scholars have critiqued the essay as lacking in historical and economic accuracy regarding pastureland sociology and economics (Cox, 1985).

Although explaining the futility and pathogenic effect of appeal to conscience in curtailing human fecundity, Hardin however illustrated and hinged much heavily on the commons as well as its exploiters' natural instinct to oversubscribe. Such scenario creates ambivalence, as reflected in this submission

\section{"The argument here has been stated in the context of the population problem, but it applies equally well to any instance in which society appeals to an individual exploiting a commons $t$ o restrain himself for the general good - by means of his conscience" (Hardin, 1968, p. 32).}

Against the backdrop of lack of working definition for the word 'commons' and mentioning the word over forty times and 'overpopulation' a mere two times, misconstruing context of the thesis may not be far-fetched. Apart from the most celebrated allegories of the herdsmen commons, the essay utilised many other literary appreciations to energise the tragedy of overpopulation. To mention a few- The metaphor of bank robbery, cooperators' loss, parking space, and ticktack-toe gaming. However, each of the literary writings was explained in terms of the idea of an insensible depletion of what belongs to no one and belongs to all. The context in which Hardin, therefore, pronounced the important thesis was rather too distracted from overpopulation to eschew misapprehension.

The most celebrated, and certainly the misleading part, of Hardin's essay was his allegorical narrative of the herdsmen and the grazing commons. He explained that the herdsmen understood that if they put too many cattle out, if they overused the resource, the resource would collapse, much like the atmosphere and our climate could collapse if we put out too many greenhouse gases into it. There was a solution, though, he said. They could agree among themselves, cooperate on a formula in which each agrees to put out only the herds that together add up to the carrying capacity of the common. The section climaxed of the irony of the cooperators' loss. Hardin also presented the tragedy of pollution, which though assigned as "a consequence of population" by the author, but nevertheless could be averted by regulation that makes "it cheaper for the polluter to treat his pollutants than to discharge them untreated". All of these present the central idea in the essay as though it bordered on collective rationality for the consummation of earth's resources (commons).

\section{Misleading retort essays by Garrett Hardin}

A major undoing of Hardin's essay is to have illustrated the idea of the 'commons' without a working definition that points unmistakably to human fecundity. Perhaps the closest the author came was 'commons in breeding'. But then there were other allusions such as commons in herding, commons in parking space and commons in waste disposal. Hardin, however, exacerbated the confusion in 1977 when he retorted that the thinking about the 'commons' is that "whatever is owned by many people should be free for the taking of anyone who feels a need for it" (Hardin, 1977, p. 47). The thesis of Hardin's essay has been clearly stated by Dietz, Ostrom and Stern (2003) as the mounting pressure on the finite natural resources from the sheer number of human being on the earth surface. The authors buttressed the strength of this position, citing from Myers and Worm (2003). The latter concluded that less that one-tenth of ocean's large predatory fishes are in existence in just about a decade and an half after the industrial revolution, and concluded that task is a sort of an unending struggle. In the face of stiff critiques due to the huge anthological success recorded by the essay, however, Garrett Hardin appears to have panicked by revising his essay six times having discovered that his "ecologist's view of the human overpopulation problem would not crystallise" and eventually "found fault with" his "own conclusions" (Hardin, 1994; Hardin, 1998, p. 682).

In the 1994 and 1998 postscripts, Hardin argued that that he was in the real sense referring to "unmanaged commons" and that a "managed commons" could not have been his target: a lump sum of texts that further misled authors in the already tumultuous misinterpretation of the original thesis. The two postscripts titled The Tragedy of the Unmanaged Commons and the Extensions of "The Tragedy of the Commons" 
published in 1994 and 1998 respectively, failed to provide necessary supportive template for the 1968 essay. If anything, they negated every essence of the thesis and further veered attention away from the important admonition about the skyrocketing population and the futility of the preponderant technical solution to the pervasive environmental crisis. By qualifying the 'commons' in 1994 and rebranding the article along the same axis, there is no doubt that the postscripts aided the bandwagon obsession towards the management strategies for extracting resource from the commons.

\section{Mislead in early comments: The bandwagon effect}

At the spurs of the moment, the indication that Hardin's essay was moving towards a huge success emerged few months after the publication in 1968. With ten years of its publication, the essay was cited across many disciplines including, but not limited to, sociology, history, economics, political science, philosophy, and public administration. A common denominator across these citations is the view about the managing the commons for the avoidance of the tragedy. Nevertheless, there are few authors that attempted to see through Hardin's thesis and extolled it. Unfortunately, voices on the right are usually dismissive. They typically rely on extolling Garrett Hardin's classic article — Most especially in realizing that he later said that he should have titled it "The Tragedy of the Unmanaged Commons".

\section{CONCLUSION}

That the collapse of the earth looms large from the present anthropogenic conditions is a position around which there appears to be a substantial agreement. The concern about lack of temperance in human fecundity, leading to overpopulation, has not been a null set since the industrial revolution. Thomas Malthus's An essay on the principle of population published in 1798 was immediately countered by William Godwin's $O f$ population: An enquiry concerning the power of increase in the number of mankind in 1820. By 1833, 1912, 1968, and 2015 William Forster Lloyd, Edward Gonner, Paul Ehrlich and Jeffrey D. Sachs respectively wrote Two lectures on the checks to population, Common land and inclosure, The population bomb, and The age of sustainable development. In 2019, Sarah Harper explored population structures and growth in How population change will transform our world. These works attached the solution to population growth to means of subsistence, political justice, common's rational management, and sustainable exploration of earth's finite resources.

Nevertheless, Hardin's essay arguably stands out for its decisiveness on "the population problem" as an end in itself, which "cannot be solved in a technical way" nor by any conscientious appeal to 'responsible fecundity'. The important resolve of Hardin is that other than a collectively agreed and coercive prohibition to curtail procreation, the devil inherent in an overpopulated earth and its manifesting collapse is inevitable. Paul Ehrlich only came close to Hardin's superior position when he submitted,
"It cannot be overemphasised...that no change in behaviour or technology can save us unless we can achieve the control over the size of human population. The birth rate must be brought into balance with the death rate or mankind will breed itself into oblivion. We can no longer afford merely to treat the cancer of population growth; the cancer itself must be cut out" (Ehrlich, 1968, p. xii).

By however adding that the "the problem" persists because "too many people" are chasing "too little food" (pp. 1-25), Ehrlich deviated from zeroing on human number as the exclusive solution to the crisis.

For close to five decades, Hardin's essay remained phenomenal in influencing the thinking of researchers in sustainable development. However, the crux of Hardin's essay appears to be laid to rest almost at the onset. Most scholars that reviewed, referenced or critiqued the essay did so for studies in the appropriateness (or otherwise) in sustainable human use of natural endowments. Arguably, the paper created an uproar that could have assisted in shaping the thinking and writings on the 'devil' of overbreeding and futility of technical reproductive solution to overpopulation crisis since 1968 when only less than half the present population were around.

The drastic "change in human values or ideas of morality" regarding human fecundity, as Hardin (1968, p. 1243) proffered, is greatly essential in the present world with unending frustration. The current global order glorifies the mobilisation of energy by those who possess it to achieve their ends, notwithstanding the means. Capitalism allows wealth accumulation for few individuals who possess the human or material resources to invest and accumulate uncensored profit. Globalisation eclipses local initiatives and means of subsistence since the 'global village' allows the multinational corporations to produce and sell at alarming scale and unimaginably competitive prices. Populism, the neonationalism currently spreading in vital nations of the Northern hemisphere, connotes exercising the political will, rightly or wrongly, to exclude 'others' from socio-economic gain. In "The politics of nature: Climate change, environmental law, and democracy", Professor Jedediah Purdy claimed that greenhouse gas emissions from one part of the world disseminate by way of diffusion to other parts irrespective of the origin. In other words, the health, environment, politics and economies of low-carbon emitting nations is not immune from the huge emissions of the industrialised nations of the West and those of the Asian Tigers. As Rane (2018) argued, the lifestyle to less than $10 \%$ of global population account for a good proportion of carbon emission that depletes the ozone layer for the entire world population. Purdy (2010) labeled the situation as "the ratio of benefit to harm all but certain to induce overindulgence" ( $p$. 1132).

In the absence of Hardin's "recognition of necessity" to coercively curtail human's freedom to breed, it is obvious that 
successively: (1) nature's "carrying capacity", using Hardin's word, would denigrate irreparably (Bosi \& Desmarchelier, 2019); (2) extinction of non-human species is not improbable (Hayes \& Hayes, 2013; Sodhi, Brook \& Bradshaw, 2009; Firstenberg, 2017); and human extinction may be currently steering humanity deep in the face (Knight, 2020). In that milieu, inequality will accentuate to greater scale than it currently exists - resulting in social exclusion of vast majority of human being. Most likely, the absolute majority could unavoidably revolt in ways that overwhelm the current finite security resources. Then, the 'devil in the number' will truly manifest.

The exponential human population growth is less impactful compared to the multiplier effects on nature's resources. This is exactly why Hardin's classic essay serves as a wake-up call before nature takes 'her revenge', using Hardin's words. In line with Hardin's humanistic and non-technical approach, the article advocates for sustainable population strategies for environmental studies. The classic essay of Garrett Hardin serves as the touchstone to benchmark scholarly efforts for examining the illogic of pursuing technical solutions to the overwhelming environmental challenges while encouraging (or at least not discouraging) unfettered human fecundity. With about 7.56 billion human population and human's dominance of the Anthropocene, my article advocates why a shift from the ideas of technological solutions to environmental crisis to the Hardinian advocacy of sustainable population strategies by way of "Mutual Coercion Mutually Agreed Upon" is more relevant now than ever before.

Followed to the declared thesis, few would dispute that Hardin's essay could have provided the pathway for unsentimental approach to studies on overpopulation. Unfortunately, the thesis was derailed, not in the least by the essay's author and its teeming referencing world.

\section{REFERENCES}

[1] Aikenhead, G. S. (2007). Humanistic perspectives in the science curriculum. In S. K. Abell \& N. G. Lederman (Eds.), The handbook of research on science education (pp. 1-36). Lawrence Erlbaum Associates, Inc.

[2] Ahn, E., \& Kang, H. (2018). Introduction to systematic review and meta-analysis. Korean journal of anesthesiology, 71(2), 103-112. https://doi.org/10.4097/kjae.2018.71.2.103

[3] Anson, J., Bartl, W., \& Kulczycki, A. (2019). Roots and fruits of population growth and social structures: Demographic and sociological vista. In J. Anson, W. Bartl \& A. Kulczycki (Eds.), Studies in the sociology of population: International perspectives (pp. 1-26). Springer

[4] Appell, G. N. (1993). Hardin's myth of the commons: The tragedy of conceptual confusions. With appendix: diagrams of forms of co-ownership. Working Paper 8. Phillips, ME: Social Transformation and Adaptation Research Institute.

[5] Balch, T. (2012). Optimizing paper titles: SEO for your research vision. https://augmentedtrader.com/2012/02/06/how-to-composea-title-for-a-technical-paper-use-colons/

[6] Bavdekar, S. B. (2016). Art of writing: Formulating the right title for a research article. Journal of the Association of Physicians of India, 64, 53-56.
[7] Bosi, S., \& Desmarchelier, D. (2019). Pollution, carrying capacity and the Allee effect. Studies in Nonlinear Dynamics \& Econometrics. DOI: 10.1515/snde-2019-0016

[8] Braun, V., Clarke, V. (2006). Using thematic analysis in psychology. Qualitative Research in Psychology, 3, 77-101. doi:10.1191/1478088706qp063oa

[9] Bromley, D. W., \& Cernea, M. M. (1989). The Management of common property natural resources: Some conceptual and operational fallacies.

[10] Cox, S. J. B. (1985). No tragedy of the commons. Environmental Ethics Discussion Paper. 7, 49-62.

[11] Crowe, B. (1969). The Tragedy of the Commons revisited. Science, 166(3909), 1103-1107. Retrieved March 26, 2021, from http://www.jstor.org/stable/1727455

[12] Dietz, T., Ostrom, E., \& Stern, P. C. (2003). The Struggle to govern the commons. Science, 302(5652), 1907-1912.

[13] Editage. (2013). Writing an effective title. An editage series on how to write a research paper, Published by Cactus Communucation.

[14] Ehrlich, P. R. (1968). The population bomb. New York: Buccaneer Books Cutchogue

[15] Feeny, D., Berkes, F., McCay, B., \& Acheson, J. (1990). The Tragedy of the Commons: twenty-two years later. Human Ecology, 18(1), 1-19. Retrieved March 26, 2021, from http://www.jstor.org/stable/4602950

[16] Firstenberg, A. (2017). The invisible rainbow: A history of electricity and life. AGB Press.

[17] Fischer, B. A., \& Zigmond, M. J. (2004). Components of a research article. A Survival Skills and Ethics Program. Accessed 29/08/2017 from www.survival.pitt.edu survival@pitt.edu.

[18] Gehrt, S. D. (1996). The human population problem: educating and changing behavior. Conservation Biology, 10, 900-903. https://conbio.onlinelibrary.wiley.com/doi/abs/10.1046/j.15231739.1996.10030900.x

[19] Gonner, E. C. K. (1912). Common land and inclosure. London: Macmillan \& Co. Limited.

[20] Grant, M. J. (2013). What makes a good title? Health Information \& Libraries Journal, 30, 259-260. DOI: 10.1111/hir.12049

[21] Hardin, G. (1968). The tragedy of the commons. 162(3859), 12431248. DOI: $10.1126 /$ science. 162.3859 .1243

[22] Hardin, G. (1971). Nobody ever dies of overpopulation. Science, 171(3971), 486-487.

[23] Hardin, G. (1993). The tragedy of the commons. Accessed from http://www.uvm.edu/ 1polya/ENVS\%20189/readings/Tragedy\%2 0of\%20the\%20Commons--Hardin\%20(1993).doc

[24] Hardin, G. (1998) Extensions of "The Tragedy of the Commons". Science, 280(5364), 682-683. DOI: 10.1126/science.280.5364.682

[25] Harding, G. (1994). The tragedy of the unmanaged commons. Trends in Ecology \& Evolution, 9(5), 199. DOI: 10.1016/01695347(94)90097-3

[26] Harper, S. (2019). How population change will transform our world. Oxford University Press

[27] Hartley J. (2012). Titles are the hardest thing: How can we make them more effective? http://blogs.lse.ac.uk/ impactofsocialsciences/2012/05/24/titles- are-hardest-more-e ective/

[28] Hayes, W. K., \& Hayes, F. E. (2013). What is the relationship between human activity and species extinctions? In S. G. Dunbar, L. J. Gibson, \& H. M. Rasi (Eds.), Entrusted: Christians and environmental care (pp. 183-197). Mexico: Adventus International University Publishers.

[29] https://www.editage.com/insights/how-to-write-an-effective-titleand-abstract-and-choose-appropriatekeywords?regid $=1504354132$.

[30] Islam, S., Ira, J. I., Kabir, K. M. A., \& Kamrujjaman, M. (2020). COVID-19 Epidemic Compartments Model and Bangladesh. Preprints. DOI: 10.20944/preprints202004.0193.v1).

[31] Jacques, T. S., \& Sebire, N. J. (2010). The impact of article titles on citation hits: an analysis of general and specialist medical journals. Journal of Royal Society of Medicine Short Report, 1(2), $1-5$. 
[32] Jermain, D. O. (1975). "Marx on population: A critical review including a comparison to Malthus and a new perspective on Marx" (1975). Dissertations and theses of the Portland State University. Paper 823. DOI: 10.15760/etd.823

[33] Jukes, T. H. (1971). Overpopulation. Science, 173(3996), 475. DOI: $10.1126 /$ science.173.3996.475-a

[34] Knight, L. (2020, January 10). Experience: I campaign for the extinction of the human race. Available at https://www.theguardian.com/lifeandstyle/2020/jan/10/icampaign-for-the-extinction-of-the-human-race-les-knight

[35] Kulkarni S. (2013). 3 basic tips on writing a good research paper title. http://www.editage.com/insights/3basic-tips-on-writing-agood-research-paper-title.

[36] Kumar MJ. (2013) Making Your Research Paper Discoverable: Title Plays the Winning Trick. IETE Technical Review, 30, 361363.

[37] Lloyd, W. F. (1833). Two Lectures on the checks to population: Delivered fefore the University of Oxford. Oxford Press

[38] Mack, C. (2012). How to write a good scientific paper: Title, abstract, and keywords, Journal of sep:Micro/Nanolithography, MEMS, and MOEMS, 11(2), 1-4.

[39] Maclellan, M. (2015). The tragedy of limitless growth: Reinterpreting the tragedy of the commons for a century of climate change. Environmental Humanities, 7, 41-58.

[40] Myers, R. A., \& Worm, B. (2003). Rapid worldwide depletion of predatory fish communities Ransom Nature, 423, pp. 280-283

[41] Nowell, L. S., Norris, J. M., White, D. E., \& Moules, N. J. (2017) Thematic Analysis: Striving to Meet the Trustworthiness Criteria. International Journal of Qualitative Methods. https://doi.org/10.1177/1609406917733847

[42] Rane, Z. (2018, October 31). Why do so many people think overpopulation will cause human extinction?Stopping overpopulation isn't how we curb resource consumption Available at https://medium.com/@zulie_rane/why-do-so-many- people-think-overpopulation-will-cause-human-extinction977369055215

[43] Rodrigues, V. (2013, Nov., 4). How to write an effective title and abstract and choose appropriate keywords. Accessed from https://www.editage.com/insights/how-to-write-an-effective-titleand-abstract-and-choose-appropriate-keywords

[44] Sachs, J. D. (2015). The age of sustainable development. Columbia University Press.

[45] Sandvik, H. (1999). On human population growth, natural selection, and the Tragedy of the Commons. Conservation Biology, 13(2), 447-449. Retrieved March 26, 2021, from http://www.jstor.org/stable/2641492

[46] Shepherd, G. (1988). The reality of the commons: Answering Hardin from Somalia. London: Overseas Development Institute, Social Forestry Network, paper 6d.

[47] Sodhi, N. S., Brook, B. W., \& Bradshaw, C. J. A. (2009). Causes and consequences of species extinctions. In S. A. Levin, S. R. Carpenter, H.C.J. Godfray, A.P. Kinzing, M. Loreau, J.B. Losos, B. Walker, \& D. S. Wilcove (Eds.), The Princeton Guide to Ecology (pp. 514-520). Princeton University Press

[48] Starkey, M. (2020, March 20). COVID-19: Pandemic and population growth. Accessed 3/6/2020 from https://www.populationconnection.org/covid-19-pandemics-andpopulation-growth/

[49] The World Bank (2021). Accessed 2/6/2021 from https://data.worldbank.org/indicator/SP.URB.TOTL.IN.ZS

[50] Vienna Scientific Sessions, (2016). The title and abstract are the most visible parts of your article. An online publication of the International Scientific Conference on Earth and Geo Sciences, 25 October, 2016, HOFBURG Vienna, Austria, accessed 01/09/17 from http://www.sgemviennagreen.org/

[51] WHO (2021, June, 2). WHO Coronavirus disease (COVID-19) dashboard. Accessed 02/06/2021 from https://covid19.who.int/ 